\title{
ANALISIS KADAR FLAVONOID DAN FENOLAT PADA KULIT BUAH MANGGIS
} (Garcininia mangostanaL.)

\author{
Analysis of Flavonoid and PhenolicLevels in Mangosteen (GarciniamangostanaL.) Bark
}

\author{
*Atika Putri Rezki, Siang Tandi Gonggo dan Sri Mulyani Sabang
}

Pendidikan Kimia/FKIP - Universitas Tadulako, Palu - Indonesia 94118

Received 01September 2017, Revised 03 October 2017, Accepted 01 November 2017

\section{Abstract}

This study aimed to determine flavonoid and phenolic levels from the mangosteen bark samples. Preparation process of the sample were performed by extraction through maceration technique using $\mathrm{HCl} 1 \%$ in ethanol and for the phenolic using ethanol. Levels of both analit were determined using a UV-Vis spectrophotometer at wavelength of $510 \mathrm{~nm}$ and $700 \mathrm{~nm}$ for the flavonoid, and $765 \mathrm{~nm}$ for the phenol. The results showed that flavonoids and phenol levels in the mangosteen bark samples were $1.271 \mathrm{mg} / \mathrm{g}$ and 12.373 $m g / g$.

Keywords: Flavonoid, phenolic, mangosteenbark, anti-oxidant.

\section{Pendahuluan}

Indonesia terkenal dengan keanekaragaman jenis buah. Salah satunya adalah buah manggis (Garcinia mangostana L.). Manggis memiliki perpaduan warna yang indah dan citarasa yang khas, yakni perpaduan rasa manis, asam dan sepat yang tidak dimiliki oleh buah lainnya. Oleh karena itu, buah manggis sering disebut sebagai buah eksotik. Selain itu, buah manggis juga mendapat sebutan Finest fruit of the Tropics dan Queen of fruits. Tanaman manggis merupakan tanaman tropis dari Asia Tenggara, tepatnya Semenanjung Malaya (Nursetiadi, 2008).

Buah manggis (Garcinia mangostana L.) merupakan buah yang digemari oleh kalangan masyarakat. Umumnya masyarakat hanya mengkonsumsi buahnya, sedangkan untuk kulitnya dibuang begitu saja. Pada masa panen limbah kulit manggis menjadi melimpah dan mencemari lingkungan. Sehingga limbah dari kulit manggis itu sendiri dapat dimanfaatkan sebagai makanan maupun minuman serta obat-obatan. Dalam kulit manggis mengandung senyawa yang berperan sebagai antioksidan seperti antosianin $(5,7-6,2 \mathrm{mg} / \mathrm{g})$, xanton dan turunannya $(0,7-34,9$ $\mathrm{mg} / \mathrm{g}$ ) (Gempita, 2012).

Senyawa lain yang terkandung dalam kulit buah manggis yaitu xanthone yang meliputi mangostin, mangosterol, mangostinon $A$ dan $B$, trapezifolixanthone, tovophyllin $B$, alfa dan beta mangostin, garcinon $B, \quad$ mangostanol, flavonoidepikatekin dan gartanin (Miryanti, dkk., 2011). Senyawa xanthone pada kulit buah manggis

*Correspondence

Atika Putri Rezki

Program Studi Pendidikan Kimia, Fakultas Keguruan dan

Ilmu Pendidikan, Universitas Tadulako

e-mail: atikarezki72@gmail.com

Published by Universitas Tadulako 2017 merupakan antioksidan tingkat tinggi karena kandungan antioksidannya 66,7 kali wortel dan 8,3 kali jeruk, selain itu sifat antioksidannya melebihi vitamin E dan vitamin C. Senyawa flavonoid termasuk senyawa fenolik alam yang potensial sebagai antioksidan dan mempunyai bioaktivitas sebagai obat. Pigmen/zat warna yang terdapat dalam tumbuh-tumbuhan seperti zat warna merah, ungu, biru, kuning, dan hijau tergolong senyawa flavonoid (Miryanti, dkk., 2011).Senyawa fenolat adalah senyawa kimia yang mempunyai gugus hidroksil (-OH terikat langsung pada cincin aromatik). Senyawa fenolat meliputi fenol sederhana, asam fenolat, turunan asam hidroksinamat dan flavonoid (Ismayanti, 2013).

Kulit buah manggis (Garcinia mangostana L.) memiliki aktivitas antibakteri (Torrungruang, dkk., 2007), antiinflamasi dan antialergi (Nakatani, dkk., 2002), antifungi (Suksasrarn, dkk., 2003), serta aktivitas antikanker; diantaranya kanker hepatoseluler dan kanker payudara (Moongkardi, dkk., 2003), dan leukemia (Matsumoto, dkk., 2004).

Antioksidan memiliki kemampuan untuk menetralisasi radikal bebas, sehingga mampu melindungi tubuh dari kerusakan stres oksidatif dan menghambat terjadinya penyakit degeneratif.Antioksidan banyak ditemukan pada sayur dan buah. Kulit buah manggis merupakan salah satu limbah buah manggis yang potensial memiliki aktivitas antioksidan alami (Gempita, 2012).

Tulisan ini akan mendeskripsikan mengenai penentuan kadar senyawa makro flavonoid dan fenolat yang terdapat dalam kulit buah manggis (Garcinia mangostana L.) . 


\section{Metode}

\section{Alat dan Bahan}

Alat-alat yang digunakan pada penelitian ini yaitu, pipet tetes, tabung reaksi, neraca analitik (Adventurer Ohaus), spatula, erlenmeyer, gelas kimia, shaker, corong, gelas ukur, rak tabung reaksi, spektrofotometer UV-Vis (Perkin Elmer Lamda 25), sendok, blender dan gunting.

Bahan yang digunakan pada penelitian ini yaitu, larutan asam galat (Merck), larutan etanol 96\% (Merck), reagen folin ciocalteu (Merck), larutan $\mathrm{Na}_{2} \mathrm{CO}_{3} 20 \%$, (Merck), larutan $\mathrm{HCl} 1 \%$ dalam etanol (Merck), larutan buffer $\mathrm{pH} 1 \mathrm{dan} \mathrm{pH}$ 4,5 (Merck), aquadest dan kertas saring.

\section{Cara preparasi sampel}

Buah manggis pada tahap ini dipisahkan antara buah dengan getah dan kulitnya. Kemudian kulit terluar dikupas dari kulit buah manggis dan cuci kulit bagian dalam hingga bersih. Selanjutnya kulit manggis dipotong menjadi kecil-kecil.Setelah itu dikeringkan menggunakan oven selama 2 hari, dan akhirnya diekstraksi secara maserasi dengan pelarut etanol.

\section{Prosedur Penelitian \\ Analisis kadar fenolat \\ Pembuatan kurva kalibrasi asam galat dengan reagen folin-ciocalteu}

Asam galat 0,25 g ditimbang, kemudian ditambahkan $5 \mathrm{~mL}$ larutan etanol 96\% setelah itu ditambahkan aquadest sampai $50 \mathrm{~mL}$. Dari larutan induk dipipet $(1,5,2,0,2,5,3,0$ dan 3,5) $\mathrm{mL}$ dan diencerkan dengan menggunakan aquadest sampai $25 \mathrm{~mL}$ sehingga dihasilkan konsentrasi $(300,400$, 500,600 , dan 700) $\mathrm{mg} / \mathrm{L}$ asam galat. Dari masingmasing kosentrasi di atas dipipet $0,2 \mathrm{~mL}$ ditambahkan $15 \mathrm{~mL}$ aquadest dan $1 \mathrm{~mL}$ reagen folin ciocalteu kemudian dikocok. Diamkan selama 8 menit dan ditambahkan $3 \mathrm{~mL}$ larutan $\mathrm{Na}_{2} \mathrm{CO}_{3} \quad 20 \%$ dan dikocok kembali sampai homogen. Setelah itu didiamkan selama 2 jam pada suhu kamar. Selanjutnya diukur serapan pada panjang gelombang maksimum $765 \mathrm{~nm}$ dan dibuat kurva kalibrasi hubungan antara kosentrasi asam galat $(\mathrm{mg} / \mathrm{L})$ dengan absorban.

\section{Penentuan kandungan fenolat total dengan metoda Folin-Ciocalteu}

$0,3 \mathrm{~g}$ filtrat ditimbang kemudian dilarutkan sampai $25 \mathrm{~mL}$ dengan etanol dan air (1:1). Setelah itu dipipet sebanyak $0,2 \mathrm{~mL}$ larutan ekstrak dan ditambahkan $15 \mathrm{~mL}$ aquadest. Lalu ditambahkan 1 $\mathrm{mL}$ reagen folin-ciocalteu dan kemudian dikocok.Selanjutnya, larutan didiamkan selama 8 menit kemudian ditambahkan $3 \mathrm{~mL} \mathrm{Na} \mathrm{CO}_{3} 20 \%$ kedalam campuran. Larutan didiamkan selama 2 jam pada suhu kamar dan diukur serapannya dengan menggunakan spektrofotometer UV-Vis pada panjang gelombang maksimum $765 \mathrm{~nm}$ yang akan memberikan komplek biru. Total fenolat sampel ditentukan dengan rumus (Ismayanti, 2013):

$$
\text { Total Flavonoid }=\frac{A \times M r \times 1000}{€ x b}
$$

dimana $\mathrm{x}=$ kosentrasi fenolat $(\mathrm{mg} / \mathrm{L})$ dan $\mathrm{Fp}=$ faktor pengenceran

\section{Analisis kadar flavonoid}

5 gram serbuk kulit buah manggis ditimbang kemudian ditambahkan pelarut $\mathrm{HCl}$ $1 \%$ dalam etanol sebanyak $50 \mathrm{~mL}$ kedalam erlenmeyer. Setelah itu campuran larutan dikocok menggunakan shaker dengan kecepatan $250 \mathrm{rpm}$ selama 2 jam. Kemudian pengekstrakan diulangi sampai warna larutan berubah (tidak seperti larutan awal) selama 4 kali. Selanjutnya larutan disaring dan dimasukkan masing-masing filtrat sebanyak $5 \mathrm{~mL}$. Setelah itu ditambahkan larutan buffer $\mathrm{pH} 1$ (tabung reaksi 1) dan $\mathrm{pH}$ 4,5 (tabung reaksi 2). Kemudian larutan diencerkan sebanyak 5 kali. Setelah itu, diukur absorbansi larutan dengan menggunakan spektrofotometer UV-Vis pada panjang gelombang $510 \mathrm{~nm}$ dan $700 \mathrm{~nm}$.

Penentuan $\mathrm{pH}$ differensial yaitu dengan mengukur absorbansi ekstrak buah pada $\mathrm{pH} 1$ dan $\mathrm{pH} 4,5$ yang diukur pada panjang gelombang 510 $\mathrm{nm}$ dan $700 \mathrm{~nm}$. Nilai absorbansi sampel ditentukan dengan rumus:

$\mathrm{A}=\{(\mathrm{A} 510-\mathrm{A} 700) \mathrm{pH} 1-(\mathrm{A} 510-\mathrm{A} 700) \mathrm{pH}$ $4,5\}$

Kandungan flavonoid sampel dihitung dengan rumus (Nugrahawati, 2010):

$$
\text { Total Flavonoid }=\frac{\mathrm{A} \times \mathrm{Mr} \times 1000}{€ \times \mathrm{xb}}
$$

dimana $\mathrm{A}=$ Absorbansi; $€=$ Absorpsivitas molar sianidin-3 glukosida $(26.900 \mathrm{~L} / \mathrm{mol} \mathrm{cm})$; b = lebar kuvet $(1 \mathrm{~cm}) ; \mathrm{Mr}=$ berat molekul sianidin-3Glukosida $(449,2 \mathrm{~g} / \mathrm{mol})$.

\section{Hasil dan Pembahasan}

\section{Analisis kadar fenolat}

Analisis kandungan total fenolat dilakukan untuk mengetahui potensi ekstrak kulit buah manggis sebagai penangkal radikal bebas dan penstabil oksigen singlet. Tubuh manusia menghasilkan senyawa antioksidan, tetapi jumlahnya seringkali tidak cukup untuk menetralkan radikal bebas yang masuk ke dalam tubuh. Komponen kimia yang berperan sebagai antioksidan adalah senyawa golongan fenolik dan polifenolik. Senyawa-senyawa golongan tersebut banyak terdapat di alam, terutama pada tumbuhtumbuhan, dan memiliki kemampuan untuk menangkap radikal bebas (Dungir, dkk., 2012).

Penentuan besarnya kandungan total fenolik kulit buah manggis digunakan persamaan kurva 
standar asam galat. Penggunaan asam galat sebagai standar dikarenakan senyawa ini sangat efektif untuk membentuk senyawa kompleks dengan reagen Folin-Ciocalteu, sehingga reaksi yang terjadi lebih sensitif dan intensif. Berdasarkan penelitian yang telah dilakukan, dapat diketahui absorbansi dari larutan standar asam galat dapat dilihat pada Table 1.

Tabel 1. Hasil pengukuran absorbansi larutan standar asam galat

\begin{tabular}{cc}
\multicolumn{2}{c}{ standar asam galat } \\
\hline Kosentrasi (ppm) & Absorbansi \\
\hline 0 & 0 \\
400 & 0,0515 \\
500 & 0,1888 \\
600 & 0,2747 \\
700 & 0,4797 \\
\hline
\end{tabular}

Hasil pengukuran absorbansi pada berbagai larutan standar asam galat diperoleh harga korelasi (r) yaitu sebesar 0,7428 . Nilai r yang mendekati 1 membuktikan bahwa persamaan regresi tersebut adalah linier antara absorbansi yang terukur dan konsentrasi.

Analisis kadar fenolat pada kulit buah manggis ditentukan dengan menggunakan kurva kalibrasi dengan cara mengukur absorbansi sampel, dimana absorbansi sampel yang diperoleh pada panjang gelombang $765 \mathrm{~nm}$ sebesar 0,0156. Hasil yang diperoleh dalam penelitian ini yakni untuk kadar fenolat kulit buah manggis sebesar 141,33 $\mathrm{mg} / \mathrm{L}$ setara dengan $1,271 \mathrm{mg} / 100 \mathrm{~g} \mathrm{Hal}$ ini memberikan petunjuk bahwa dalam 10 gram kulit buah manggis terdapat $\pm 1,271 \mathrm{mg}$ fenolat.

Menurut Dungir, dkk. (2012), tentang kadar fenolat dengan menggunakan pelarut metanol sampel basa, metanol sampel kering dan air sampel basa dan air sampel kering berturutturut diperoleh kadar yaitu 15,5\%, 21\%, 11\% dan $12 \%$. Tingginya kandungan fenol yang terekstraksi dikarenakan pengaruh pelarut yang digunakan untuk ekstraksi. Pelarut seperti metanol dan etanol merupakan pelarut yang sangat luas digunakan dan efektif untuk ekstraksi komponen-komponen fenolik dari bahan alam (Katja \& Suryanto, 2009). Molekul sederhana yaitu senyawa fenolik, sampai dengan molekul kompleks seperti tanin (tanin terhidrolisis dan tanin terkondensasi). Senyawasenyawa fenolik dilaporkan dapat bereaksi dengan senyawa oksigen reaktif, hal ini disebabkan satu atau dua gugus hidroksi pada cincin aromatik yang bisa berperan sebagai donor hidrogren (Dungir, dkk., 2012).

\section{Analisis kadar flavonoid}

Analisis kadar flavonoid pada kulit buah manggis dapat ditentukan dengan menggunakan alat spektrofotometer UV-Vis pada panjang gelombang $510 \mathrm{~nm}$ dan $700 \mathrm{~nm}$, dimana nilai absorbansi yang diperoleh yakni sebesar 0,0437 . Hasil kadar flavonoid sebesar 3,6487 mg/L setara dengan $12,373 \mathrm{mg} / 100 \mathrm{~g}$. Hal ini memberikan petunjuk bahwa dalam 5 gram kulit buah manggis terdapat $\pm 12,373 \mathrm{mg}$ fenolat.

Flavonoid merupakan senyawa polifenol yang memiliki fungsi sebagai senyawa antibakteri dengan cara membentuk senyawa kompleks terhadap protein ekstraseluler yang mengganggu integritas membran sel bakteri. Flavonoid berfungsi sebagai antibakteri dengan cara membentuk senyawa kompleks terhadap protein extraseluler yang mengganggu integritas membran sel bakteri (Wijaya, dkk., 2014).

Menurut Makaryanti (2014) kandungan flavonoid dalam $500 \mathrm{~g}$ sampel kulit buah manggis sebesar 396,85 $\pm 23,26$ QE. Menurut Setyaningrum (2010), kadar antosianin dalam 100 gram sampel kulit buah manggis dengan menggunakan pelarut aseton dengan variasi larutan $\mathrm{HCl} 1 \%$ diperoleh kadar sebesar 0,15 mg. Antosianin merupakan golongan senyawa flavonoid yang memiliki fungsi sebagai antioksidan alami. Adanya perbedaan kadar flavonoid disebabkan jumlah massa kulit buah manggis yang berbeda dan juga biasa dipengaruhi oleh proses ekstraksinya.

Faktor-faktor yang dapat mempengaruhi hasil ekstraksi adalah waktu ekstraksi, pH dan temperatur ekstraksi. pH larutan ekstraksi berpengaruh terhadap kestabilan warna pigmen. Menurut Tensiska, dkk. (2007) ekstraksi senyawa golongan flavonoid dianjurkan dilakukan pada suasana asam karena asam berfungsi mendenaturasi membran sel tanaman, kemudian melarutkan pigmen antosianin sehingga dapat keluar dari sel, serta dapat mencegah oksidasi flavonoid. Senyawa golongan flavonoid termasuk senyawa polar dan dapat diekstraksi dengan pelarut yang bersifat polar pula. Beberapa pelarut yang bersifat polar diantaranya etanol, air dan etil asetat (Setyaningrum, 2010).

\section{Kesimpulan}

Kadar flavonoid pada kulit buah manggis dianalisis menggunakan spektrofotometer UV-Vis diperoleh kadar sebesar $12.373 \mathrm{mg} / 100 \mathrm{~g}$. Sedangkan kadar fenolat pada kulit buah manggisdiperoleh kadar sebesar $1.271 \mathrm{mg} / 100 \mathrm{~g}$.

\section{Ucapan Terima kasih}

Penulis mengucapkan terima kasih kepada pihak yang telah membantu penelitian ini, khususnya kepada laboran Laboratorium Penelitian Kimia Fakultas Matematika dan Ilmu pengetahuan Alam Universitas Tadulako Palu, Sulawesi Tengah atas bantuannya selama penulis melaksanakan penelitian.

\section{Referensi}

Dungir, S. G., Katja, D. G., \& Vanda, S. (2012). Aktivitas antioksidan dan ekstrak fenolik dari kulit buah manggis (garcinia mangostana l.). Jurnal MIPA Unsrat Online, 1(1), 11-15. 
Gempita, C. N. (2012). Pengaruh berbagai pH dari sari buah dan subu pasteurisasi terhadap aktivitas antioksidan dan tingkat penerimaan sari kulit buah manggis. Skripsi Semarang: Univesitas Diponegoro.

Ismayanti. (2013). Kajian kadar fenolat total dan aktivitas antioksidan jus kulit buah semangka (citrullus lanatus). Skripsi Palu: Universitas Tadulako.. Tidak diterbitkan.

Katja, D. G., \& Suryanto. (2009). Efek penstabil oksigen singlet ekstrak pewarna dari daun bayam terhadap fotooksidasi asam linoleat, protein, dan asam askorbat. Chemistry Progress, 2(2), 79-86.

Makaryanti, R. Y. (2014). Potensi antioksidan ekstrak etanol daun kemuning (murraya paniculata L.) dan kulit manggis (garciniamangostana l.) dengan metode FTC $D A N$ DPPH. Skripsi. Surakarta: Universitas Muhamadiyah Surakarta.

Matsumoto, K., Akao, Y. Y. H., Ohguchi, K., Ito, T., Tanaka, T., Kobayashi, E., Linuma, M., \& Nozawa, Y. (2004). Preferential target is mitochondria in a mangostin-induced apoptosis in human leukimia HL 60 cells. Bioorganic Medicinal Chemistry, 12, 5799 5806.

Miryanti, Y. I. P. A., Sapei, L., Budiono, K., \& Indra, S. (2011). Ekstraksi antioksidan dari kulit buah manggis (garcinia mangostana l.).Skripsi. Bandung: Universitas Parahyangan.

Moongkardi, P., Kosem, N., Kaslungka, S., Luanratana, O., Pongpan, N., \& Neungton, N. (2003). Antipoli feration, antioxidant and induction of apoptosit by garcinia mangostana 1 (mangosteen) on SKBR human breast cancer cell line. Journal Ethnopharmacology, 90(1), 161-166.

Nakatani, K., Atsumi, M. T., Dosawa, K., Shimura, S., Nakanata, N., \& Ohizumi, Y. (2002). Inhibitions of his famine release and prostaglandin $\mathrm{E}_{2}$ ynthesis by mangosteen, a Thai medicinal plant. Biological Pharmaceutical Bulletin, 25(9), 1137-1141.

Nugrahawati, A. Y. (2010). Pengaruh berbagai variasi subu dan warna kemasan terhadap stabilitas antosianin kulit manggis (garcinia mangostana l.). Skripsi. Surakarta: Universitas Sebelas Maret.

Nursetiadi, E. (2008). Kajian macam media dan konsentrasi bap terhadap multiplikasi tanaman manggis (garcinia mangostana l.) secara invitro.. Skripsi. Surakarta: Universitas Sebelas Maret.

Setyaningrum, E. N. (2010). Efektivitas penggunaan jenis asam dalam proses ekstraksi pigmen antosianin kulit manggis (garcinia mangostana l.) dengan penambahan aseton 60\%. Skripsi. Surakarta: Universitas Sebelas Maret.

Suksasrarn, S., Suwannapoch, N., Phakhodee, W., Thanuhirauled, J., Ratananukul, P., Chimnoi, N \& Suksamrarn, A. (2003). Antimycrobacterial activity of prenylated xanthones from the fruits of garcinia mangostana. Chemistry Pharmacetical Bulletin, 51(7), 357-859.

Tensiska., E., Sukarminah, \& Natalia, D. (2007). Ekstraksi pewarna alami dari buah arben (rubus idaeus (linn.)) dan aplikasinya pada sistem pangan.Jurnal Teknologi dan Industri Pangan., XVIII(1), 1-7.

Torrungruang, K., Piraporn, V., \& Suchada. (2007). Antibacterial activity of mangosteen pericarp extract against cariogenic streptococcus mutans. Chulalongkorn University Dental Journal, 30(1), 1-10.

Wijaya, B. A., Citraningtyas, G., \& Wehantouw, F. (2014). Potensi ekstrak etanol tangkai daun talas (colocasia esculenta (l)) sebagai alternatif obat luka pada kulit kelinci (oryctolagus cuniculus). Jurnal Ilmiah Farmasi., 3(3), 1-9. 